\title{
Overweight and Obesity Among The Army Personnel with Low Socio-Economic Status In Kuala Lumpur: A Cross-Sectional Study
}

Nik Qistina NAR

Universiti Putra Malaysia Fakulti Perubatan dan Sains Kesihatan

Nor Afiah MZ ( $\square$ norafiah@upm.edu.my)

aculty of Medicine and Health Sciences, Universiti Putra Malaysia https://orcid.org/0000-0001-75055071

\section{Arshil Moideen}

Tuanku Mizan Armed Forces Hospital: Hospital Angkatan Tentera Tuanku Mizan

\section{Rozali Ahmad}

Tuanku Mizan Armed Forces Hospital: Hospital Angkatan Tentera Tuanku Mizan

\section{Research}

Keywords: overweight, obesity, army predictors, low socioeconomic status, military

Posted Date: March 15th, 2021

DOl: https://doi.org/10.21203/rs.3.rs-307025/v1

License: (c) (i) This work is licensed under a Creative Commons Attribution 4.0 International License. Read Full License 


\section{Abstract}

Background: The prevalence of overweight and obesity in adults worldwide was $52 \%$, which is a major public health concern. Military institutions worldwide were also plagued with this problem. $57.2 \%$ of the army personnel in Malaysia were overweight and obese, in which $52.6 \%$ had low socioeconomic status (SES). This led to negative impacts on the overall combat readiness due to the obesity-associateddiseases. This study determined the prevalence and predictors of overweight and obesity among the low SES army personnel in Kuala Lumpur.

Methods: A cross-sectional study was conducted using a proportionate random sampling among 772 army personnel from low SES group in army camps in Kuala Lumpur. Online questionnaires were distributed while latest anthropometric measurements' data were obtained from the Military Lifetime Health Record (MLHR) system. The outcome of this study was overweight and obesity (BMI of $\geq$ $25 \mathrm{~kg} / \mathrm{m}^{2}$ ). Data were analysed using SPSS version 23.0 involving descriptive and inferential statistics.

Results: The median age of the respondents was $30(\mathrm{IQR}=7)$ years. The prevalence of overweight and obese army personnel was $41.1 \%$ (95\% Cl:37.6-44.6). The predictors found were being married (AOR:2.026, 95\%Cl:1.318-3.113), secondary education (AOR:2.545, 95\%Cl:1.245-5.203), Lance Corporal (AOR:1.994, 95\%Cl:1.061-3.748), Corporal (AOR:2.814, 95\%Cl:1.578-5.020), Sergeant (AOR:4.174, 95\%Cl:2.076-8.390), past injury (AOR:1.879, 95\%Cl: 1.191-2.965), history of obese sibling (AOR:1.737, 95\%Cl:1.013-2.973), history of obese parent (AOR:3.344, 95\%Cl:1.965-5.688), history of obese grandparent (AOR:11.321, 95\% Cl:2.207-58.072), poor knowledge on dietary intake (AOR:1.524, 95\%Cl:1.077-2.157), less than 2 litres daily plain water intake (AOR:1.606, 95\%Cl:1.166-2.210).

Conclusions: Knowledge on dietary intake and plain water intake are the two modifiable predictors for overweight and obesity found in this study, while the other nine predictors are non-modifiable. Understanding on issues surrounding the low SES group will help the strategic level in planning for future comprehensive interventions on overweight and obesity, specifically targeting on those predictors.

\section{Background}

In 2016, World Health Organisation revealed that $52.2 \%$ adults (18 years and above) worldwide fell into the overweight and obesity group. Overweight and obesity are defined as abnormal or excessive fat accumulation that has negative impact on one's health [1]. In Malaysia, the national survey reported that the prevalence of overweight and obesity among adults (18 years and above) has increased significantly from $21.0 \%$ in 2005 to $50.1 \%$ in 2019 [2].

The military organization in Malaysia puts great emphasis on physical profile and fitness of the soldiers to maintain the overall force readiness. Despite that, the organization is still not spared from this problem. Little information can be deduced from published literature on the prevalence of overweight and obesity in the military organization in Malaysia [3]. A cross-sectional study in Malaysia, involving 913 military personnel from an army division in 2015, found high percentage of overweight and obesity, at 
$57.2 \%$ [4]. The same study, also found that overweight and obesity was much higher in the low socioeconomic status (SES) group as compared to high SES group (52.6\% and $4.6 \%$ respectively) [4].

In military institutions worldwide, sociodemographic factors [5, 6], family history of obesity [7], lifestyle factors such as diet intake [8], physical activity [9], sleep quality [10], stress factor [11] and readiness to change factor [12] are often associated with overweight and obesity. However, in the military organization in Malaysia, previous studies only reported the relationship between socio-demographic to overweight and obesity [4], rendering the relationship with other factors left unknown. The military organization in Malaysia has different social and physical environment, distinctly different from the general populations. Hence, specific understanding of all of the factors causing overweight and obesity is crucial.

Overweight and obesity is also associated with non-communicable diseases. No publication on the prevalence of non-communicable diseases (NCDs) among army personnel was found. In a systematic review of 74 longitudinal or cross-sectional studies among 90,758 Chinese military personnel between Year 2000 to 2016, there were high prevalence rates of hypertension, hyperlipidaemia, diabetes mellitus, heart diseases, cerebrovascular diseases and chronic obstructive pulmonary diseases [13]. Mild obesity was associated with the loss of one in ten, and in severe obesity, the loss of one in four potential diseasefree years from major non-communicable diseases during middle and later adulthood [14]. The loss of disease-free years will further affect the career progression of the low socioeconomic status personnel, and may lead to dismissal from the military service.

In view of the increasing cost of living and widening of socio-economic status gap in Malaysia, the low SES group has received more attention from the government and top military commanders. Overweight and obesity problems among them will lead to a vicious cycle of non-career progression and low-income category in long run, hence a greater health and financial burden to the country especially upon their retirement. The findings from this study will assist the top commanders to understand the predictors of overweight and obesity among the soldiers, especially in the low SES group. This in turn, will become the basis for new policy development, new health intervention programs and a comprehensive social support plan for this group in order to optimise healthy lifestyle, reduce the prevalence of overweight and obesity and reduce the overall financial burden related to its complications in the military organization. Findings from this study may also be a good reference for any health education programme involving army personnel. These efforts are also in line with the Sustainable Developmental Goal No 3.4 [16].

\section{Method}

This cross-sectional study was conducted from September 2019 to July 2020 among 772 active-duty army personnel from Other Ranks with household income less than RM 3860, working under the formations/units in the army camps located in Kuala Lumpur, Malaysia. Their income group are categorised under the low SES group according to the Malaysian National Registration Department, 2019 [17]. 
Proportionate random sampling of all army personnel from camps in Kuala Lumpur was used to select the respondents. The sample size was calculated using the two proportions formula [18] from a population-based research by National Health and Morbidity Survey (2015) in Malaysia [19]. The $P_{1}$ used was 0.174 (from proportion of young age group with obesity and overweight), $P_{2}$ was 0.292 (from proportion of old age group with obesity and overweight) and $P$ value was 0.233 with $95 \%$ Confidence Interval and $80 \%$ power which made up to 722 for total sample size [19]. Those who were at mission area or attending courses, physically handicapped, had history of using steroids either as medication or supplements, who were in the transition training or leaving the service in the next 3 years (in weaning-offtraining phase) and who were under the Body Building Team were exempted. Besides that, army personnel working in training centres, university and army hospitals were all excluded from this study as they might have different training routines.

Self-administered online questionnaires were distributed to the selected eligible army personnel. The questionnaire consists of all independent variables such as: sociodemographic factors, 9 items; current health status, past medical history and family history of obesity, 3 items; knowledge on physical activity, 15 items [20]; knowledge on dietary intake, 15 items [21]; physical activity, 6 items [22]; dietary intake, 18 items [23]; sleep quality, 9 items [24]; smoking status, 9 items [25]; stress, 25 items [26]; and readiness to change, 32 items [27]. The questionnaire was adapted in Malay language from previous validated questionnaires in several past studies which were related to this study using factor analysis. Face and content validity were done where by all comments were taken and appropriate correction were made for further improvement of the questionnaire. The reliability of the questionnaire was measured by intraclass correlation coefficient (ICC) with the value between 0.7 to 0.8 .

Officer in charge in each Army units were tasked to make sure that all selected army personnel able to provide response via the online link within the time duration given. All study variables were extracted from the Google document "Cloud" database contained each respondent' answers of the self-administered online questionnaire. Army Identification Numbers were asked to be filled by the respondents as an identifier. However, to ensure confidentiality of the online data, measures were taken to make the Google document "Cloud" password protected, which can be opened only by the researcher. Following this, their Army Identification Numbers were used as the identifier to match the data from the online questionnaire to each record from the Military Lifetime Health Record (MLHR) system. The anthropometric measurements data (weight and height) taken from each respondents' latest PULHEEMS (Physical, Upper Limb, Lower Limb, Hearing, Right Eye, Left Eye, Mental state and Stability) medical examination record from December 2019 to February 2020 were analysed. Those data had been obtained and inserted into the MLHR system by military health practitioner in respective Army units in Kuala Lumpur. All the data collected was verified by relevant Medical Officers from each of the unit involved.

BMI was calculated for each respondent before analysis. BMI of $\geq 25 \mathrm{~kg} / \mathrm{m}^{2}$ used to classify overweight and obesity as per WHO BMI classification. Data were analysed using SPSS version 23.0 involving descriptive and inferential statistics. All of the continuous data were categorized to categorical data such as age, BMI, knowledge score, time of taking the meals and sleep duration. For bivariate analysis, chi- 
square and simple logistic regression were used. For multivariable analysis, multiple logistic regression tests were used. This study used a level of significance of 0.05 with confidence interval of $95 \%$.

\section{Results}

\section{Demographic characteristics}

The response rate was $96.5 \%$. A total of 772 army personnel from the low SES category participated in this study. The age of respondents ranging from 20 to 37 years old, with median age of 30 (IQR:7). Descriptive characteristics of the study participants are presented in Table 1. Majority of the respondents were 30 to 34 years of age (36.3\%), male (81.9\%), Islam (90.8\%), Malay (88.1\%), married $(67.7 \%)$, have poor socioeconomic status (93.7\%), in Corporal (KPL) rank (52.2\%), with at least having secondary education (83.7\%), in Combat Service Support element (42.6\%) and with 5 to 15 year experience in service (61.7\%). 
Table 1

Sociodemographic characteristics of the respondents ( $N=772$ )

\begin{tabular}{|c|c|c|c|c|}
\hline Characteristic & & Median (IQR) & Frequency & Percentage \\
\hline \multirow[t]{4}{*}{ Age group (years) } & $20-24$ & $30(7)$ & 99 & 12.8 \\
\hline & $25-29$ & & 260 & 33.7 \\
\hline & $30-34$ & & 280 & 36.3 \\
\hline & $35-39$ & & 133 & 17.2 \\
\hline \multirow[t]{2}{*}{ Gender } & Male & & 632 & 81.9 \\
\hline & Female & & 140 & 18.1 \\
\hline \multirow[t]{3}{*}{ Religion } & Islam & & 701 & 90.8 \\
\hline & Hindu & & 18 & 2.3 \\
\hline & Christian & & 53 & 6.9 \\
\hline \multirow[t]{4}{*}{ Ethnicity } & Malay & & 680 & 88.1 \\
\hline & Chinese & & 2 & 0.3 \\
\hline & Indian & & 18 & 2.3 \\
\hline & Others & & 72 & 9.3 \\
\hline \multirow[t]{4}{*}{ Marital Status } & Single & & 229 & 29.7 \\
\hline & Married & & 523 & 67.7 \\
\hline & Divorcee & & 19 & 2.5 \\
\hline & Widow/Widower & & 1 & 0.1 \\
\hline \multirow[t]{2}{*}{ SES } & $\leq \mathrm{RM} 950$ & & 49 & 6.3 \\
\hline & RM 951 to RM 3860 & & 723 & 93.7 \\
\hline \multirow[t]{4}{*}{ Rank } & Private (PBT) & & 146 & 18.9 \\
\hline & Lance Corporal (LKPL) & & 131 & 17.0 \\
\hline & Corporal (KPL) & & 403 & 52.2 \\
\hline & Sergeant (SGT) & & 92 & 11.9 \\
\hline \multirow[t]{3}{*}{ Level of Education } & Secondary Education & & 646 & 83.7 \\
\hline & Post-secondary Education & & 67 & 8.7 \\
\hline & Tertiary Education & & 59 & 7.6 \\
\hline Type of Elements/Trade & Combat & & 240 & 31.1 \\
\hline
\end{tabular}




\begin{tabular}{|llcc|}
\hline Characteristic & Median (IQR) & Frequency & Percentage \\
\hline & Combat Support & 203 & 26.3 \\
\hline Years of Service & Combat Service Support & 329 & 42.6 \\
& Less than 5 years & 157 & 20.3 \\
\hline & 5 to 15 years & 476 & 61.7 \\
\hline & More than 15 years & 139 & 18.0 \\
\hline
\end{tabular}

Prevalence of overweight and obesity among the army personnel with low socioeconomic status in Kuala Lumpur camps

The overall median BMI among the army personnel with low socioeconomic status in Kuala Lumpur was $24.32 \pm 4.29 \mathrm{~kg} / \mathrm{m}^{2}$. The prevalence of overweight and obesity among the respondents were $41.1 \%(\mathrm{n}=$ $317)$.

Associated factors of overweight and obesity among the army personnel with low socioeconomic status

Out of 39 factors studied, only 11 factors have significant relationships with overweight and obesity which are age $(x 2=44.529, d f=3, p<0.001)$, marital status $(x 2=48.601, d f=2, p<0.001)$, rank $(x 2=$ 53.829, $d f=3, p<0.001)$, level of education $(x 2=12.814, d f=2, p=0.002)$, year of service $(x 2=46.921$, $d f$ $=2, p<0.001)$, current health status $(x 2=8.061, d f=3, p=0.045)$, past medical illness $(x 2=7.095, d f=1$, $p=0.008)$, past injury $(x 2=9.383, d f=1, p=0.002)$, family history of obesity $(x 2=33.144, d f=1, p<$ $0.001)$, knowledge on dietary intake $(x 2=8.707, d f=1, p=0.003)$ and plain water intake $(\chi 2=6.145, d f=$ $1, p=0.013$ ) (details in Table 2). 
Table 2

Associated factors of overweight and obesity among the army personnel with low socioeconomic status in Kuala Lumpur camps

\begin{tabular}{|c|c|c|c|c|c|c|c|}
\hline & \multicolumn{3}{|c|}{ Chi Square Test } & \multicolumn{4}{|c|}{ Simple Logistic Regression } \\
\hline & $\mathcal{X}^{2}$ & df & $\begin{array}{l}\text { p- } \\
\text { value }\end{array}$ & $\begin{array}{l}\text { Crude } \\
\text { OR }\end{array}$ & $95 \% \mathrm{Cl}$ & & $\begin{array}{l}\mathrm{p}- \\
\text { value }\end{array}$ \\
\hline & & & & & Lower & Upper & \\
\hline Age group (years) & 44.529 & 3 & $<_{0.001}$ & & & & $\begin{array}{l}<.001 \\
0.00\end{array}$ \\
\hline $20-24$ & & & & 1.000 & & & \\
\hline $25-29$ & & & & 0.156 & 0.082 & 0.298 & $\dot{0} 001$ \\
\hline $30-34$ & & & & 0.503 & 0.329 & 0.768 & 0.001 \\
\hline $35-39$ & & & & 0.825 & 0.545 & 1.247 & 0.825 \\
\hline Marital Status & 48.601 & 2 & $\begin{array}{l}< \\
0.001\end{array}$ & & & & $\begin{array}{l}<.001 \\
0.001\end{array}$ \\
\hline Single & & & & 1.000 & & & \\
\hline Married & & & & 3.346 & 2.346 & 4.774 & $\begin{array}{l}<.001 \\
0.00\end{array}$ \\
\hline Divorcee/Widow & & & & 3.878 & 01.496 & 10.056 & 0.005 \\
\hline Rank & 53.829 & 3 & $\begin{array}{l}< \\
0.001\end{array}$ & & & & $\begin{array}{l}<.001 \\
0.00\end{array}$ \\
\hline Private (PBT) & & & & 1.000 & & & \\
\hline Lance Corporal (LKPL) & & & & 2.940 & 1.673 & 5.166 & $\begin{array}{l}<.001 \\
0.00\end{array}$ \\
\hline Corporal (KPL) & & & & 4.719 & 2.922 & 7.620 & $\begin{array}{l}<.001 \\
0.00\end{array}$ \\
\hline Sergeant (SGT) & & & & 6.323 & 3.469 & 11.527 & $\begin{array}{l}<.001 \\
0.00\end{array}$ \\
\hline Level of Education & 12.814 & 2 & 0.002 & & & & 0.003 \\
\hline Tertiary Education & & & & 1.000 & & & \\
\hline Post-secondary Education & & & & 2.186 & 0.975 & 4.899 & 0.058 \\
\hline Secondary Education & & & & 3.015 & 1.570 & 5.792 & 0.001 \\
\hline Years of Service & 46.921 & 2 & $<_{0.001}$ & & & & $\hat{0}_{0.001}$ \\
\hline
\end{tabular}




\begin{tabular}{|c|c|c|c|c|c|c|c|}
\hline & \multicolumn{3}{|c|}{ Chi Square Test } & \multicolumn{4}{|c|}{ Simple Logistic Regression } \\
\hline Less than 5 years & & & & 1.000 & & & \\
\hline 5 to 15 years & & & & 3.286 & 2.122 & 5.087 & $\begin{array}{l}< \\
0.001\end{array}$ \\
\hline More than 15 years & & & & 5.574 & 3.312 & 9.380 & $<.001$ \\
\hline Current Health Status (PULHEEMS) & 8.061 & 3 & 0.045 & & & & 0.085 \\
\hline Status Nil (PES NIL) & & & & 1.000 & & & \\
\hline Fit Everywhere (FE) & & & & 1.124 & 0.404 & 3.126 & 0.823 \\
\hline $\begin{array}{l}\text { Line of Communication } \\
\text { Everywhere (LE) }\end{array}$ & & & & 6.667 & 1.047 & 42.431 & 0.045 \\
\hline Base Everywhere (BE) & & & & 2.143 & 0.521 & 8.814 & 0.291 \\
\hline Past Medical Illness & 7.095 & 1 & 0.008 & & & & \\
\hline No & & & & 1.000 & & & \\
\hline Yes & & & & 2.349 & 1.233 & 4.476 & 0.009 \\
\hline Past Injury & 9.383 & 1 & 0.002 & & & & \\
\hline No & & & & 1.000 & & & \\
\hline Yes & & & & 1.903 & 1.255 & 2.886 & 0.002 \\
\hline Family History of Obesity & 33.144 & 1 & $\begin{array}{l}<.001 \\
0.00\end{array}$ & & & & $\begin{array}{l}< \\
0.001\end{array}$ \\
\hline No family history & & & & 1.000 & & & \\
\hline Sibling & & & & 1.918 & 1.163 & 3.162 & 0.011 \\
\hline Parent & & & & 1.880 & 1.880 & 5.034 & $<.001$ \\
\hline Grandparent & & & & 1.694 & 1.694 & 36.934 & 0.009 \\
\hline Knowledge on Dietary Intake & 8.707 & 1 & 0.003 & & & & \\
\hline Good & & & & 1.000 & & & \\
\hline Poor & & & & 1.604 & 1.171 & 2.198 & 0.003 \\
\hline Plain Water Intake (daily) & 6.145 & 1 & 0.013 & & & & \\
\hline More than 2 litres & & & & 1.000 & & & \\
\hline Less than 2 litres & & & & 1.439 & 1.079 & 1.921 & 0.013 \\
\hline
\end{tabular}


Predictors of overweight and obesity among the army personnel with low socioeconomic status

All methods; Backward LR and Forward LR methods were used to analyse the seventeen variables and subsequently, eleven predictors were finally obtained using the FORWARD LR method. Criteria of $p<0.25$ was used in selecting the variables to the Multivariable analysis.

The eleven predictors for overweight and obesity among the army personnel with low SES in Kuala Lumpur camps were: married (AOR: 2.026, 95\% Cl: 1.318-3.113), secondary education (AOR: 2.545, 95\% Cl: 1.245-5.203), rank of Lance Corporal (AOR: 1.994, 95\% Cl: 1.061-3.748), Corporal (AOR 2.814, 95\% Cl: 1.578-5.020), Sergeant (AOR: 4.174, 95\% Cl: 2.076-8.390), past injury (AOR: 1.879, 95\% Cl: $1.191-$ 2.965), obese siblings (AOR: 1.737, 95\% Cl: 1.013-2.973), obese parents (AOR: 3.344, 95\% Cl: $1.965-$ 5.688), obese grandparents (AOR: 11.321, 95\% Cl: 2.207-58.072), knowledge on diet intake (AOR: 1.524, 95\% Cl: 1.077-2.157) and plain water intake (AOR: 1.606, 95\% Cl: 1.166-2.210), as per shown in Table 3. $\mathrm{R}$ squared residual for the final predictive model was $21.5 \%$. The final model fit has a good fit as evidenced by Hosmer and Lemeshow goodness of fit test ( $\left.\mathcal{X}^{2}=5.505, \mathrm{~d} f=8, \mathrm{p}=0.702\right)$ with $79.0 \%$ specificity and $56.5 \%$ sensitivity. Demonstrated ROC curve for the final model is 0.751 (95\% Cl:0.701$0.788)$. 
Table 3

Predictors for overweight and obesity among the army personnel with low socioeconomic status in Kuala Lumpur camps

\begin{tabular}{|c|c|c|c|c|c|}
\hline \multirow[t]{2}{*}{ Factors } & \multicolumn{2}{|c|}{ Overweight and Obesity, n(\%) } & \multirow[t]{2}{*}{ AOR } & \multirow[t]{2}{*}{$95 \% \mathrm{Cl}$} & \multirow[t]{2}{*}{ p } \\
\hline & Yes & No & & & \\
\hline \multicolumn{6}{|l|}{ Marital Status } \\
\hline \multirow[t]{2}{*}{ Married } & $256(48.9)$ & $267(51.1)$ & 2.026 & 1.318 & 0.001 \\
\hline & & & & 3.113 & \\
\hline Single & $51(22.3)$ & 178(77.7) & 1.000 & & \\
\hline \multicolumn{6}{|l|}{ Level of Education } \\
\hline Secondary & $281(43.5)$ & $365(56.5)$ & 2.545 & 1.245 & 0.010 \\
\hline Education & & & & 5.203 & \\
\hline Tertiary Education & $12(20.3)$ & $47(79.6)$ & 1.000 & & \\
\hline \multicolumn{6}{|l|}{ Rank } \\
\hline \multirow[t]{2}{*}{ Lance Corporal (LKPL) } & $48(36.6)$ & $83(63.4)$ & 1.994 & 1.061, & 0.032 \\
\hline & & & & 3.748 & \\
\hline \multirow[t]{2}{*}{ Corporal (KPL) } & 194(48.1) & 209(51.9) & 2.814 & 1.578, & $<0.001$ \\
\hline & & & & 5.020 & \\
\hline \multirow[t]{2}{*}{ Sergeant (SGT) } & $51(55.4)$ & $41(44.6)$ & 4.174 & 2.076, & $<0.001$ \\
\hline & & & & 8.390 & \\
\hline Private (PBT) & $24(16.4)$ & $122(83.6)$ & 1.000 & & \\
\hline \multicolumn{6}{|l|}{ Past Injury } \\
\hline \multirow[t]{2}{*}{ Yes } & $57(54.8)$ & $47(45.2)$ & 1.879 & 1.191, & 0.007 \\
\hline & & & & 2.965 & \\
\hline No & $260(38.9)$ & $408(61.1)$ & 1.000 & & \\
\hline \multicolumn{6}{|l|}{ Family History of Obesity } \\
\hline \multirow[t]{2}{*}{ Sibling } & $36(52.2)$ & $33(47.8)$ & 1.736 & 1.013, & 0.045 \\
\hline & & & & 2.973 & \\
\hline \multirow[t]{2}{*}{ Parent } & $49(63.6)$ & $28(36.4)$ & 3.344 & 1.965, & $<0.001$ \\
\hline & & & & 5.688 & \\
\hline
\end{tabular}




\begin{tabular}{|clllll|}
\hline Factors & Overweight and Obesity, n(\%) & AOR & $95 \% \mathrm{Cl}$ & P \\
\hline Grandparent & $9(81.8)$ & $2(18.2)$ & 11.321 & 2.207, & 0.004 \\
& & & & 58.072 & \\
\hline No Family History & $223(36.3)$ & $392(63.7)$ & 1.000 & & \\
\hline Knowledge on Dietary Intake & & & & & \\
\hline Poor & $234(44.7)$ & $290(55.3)$ & 1.524 & $1.077,2.157$ & 0.017 \\
\hline Good & $83(33.5)$ & $165(66.5)$ & 1.000 & & \\
\hline Plain Water Intake & & & & & 0.004 \\
\hline Less than 2 litres a day & $161(45.9)$ & $190(54.1)$ & 1.606 & $1.166,2.210$ \\
\hline More than 2 litres per day & $156(37.1)$ & $265(62.9)$ & 1.000 & & \\
\hline
\end{tabular}

\section{Discussion}

A descriptive analysis comparison of the findings from this study indicates a high prevalence of overweight and obesity among the army personnel with low SES in Kuala Lumpur camps (41.1\%). This is consistent with both studies by Reyes et al. (2015) [33] in the United States Army and Hattachote et al. (2019) [9] in the Royal Thai Army, however, when compared with the Malaysian National Health Morbidity Survey 2019 [2], the prevalence obtained in this study was lower by $9 \%$. Similarly, the obese prevalence obtained in this study was also smaller by $13.8 \%$ as compared to another study done among the low SES group by Razni et al. (2015) [4], while the overweight prevalence was almost similar at $38.0 \%$. This study showed that about more than one third of the army personnel in each camp in Kuala Lumpur were either overweight or obese.

Married personnel, are more likely to be overweight and obese as compared to those who are single [29]. Living without a partner, either being single or divorced/widow/widower was associated with lower body weight $(p<0.05)[30]$. The reason might be due to the variety of food choices provided by their spouses, as compared to the pre-planned food menu approved by local administration for the army personnel who were single. Thus, the food portion's they took and the nutrition might be different. Support system such as spouses is needed as to motivate individuals towards healthy lifestyle. Poor support system can lead to increase in BMI in married couple especially among those who has obese spouse [31].

The second predictors of overweight and obesity in this study was secondary education. Ghee (2016) in a systematic review, mentioned that the obesity rate was lower in those with higher education background, and lowest among those with tertiary education background [32]. Higher level of education increases the obesity awareness and trend of healthy lifestyle, hence reducing the occurrence of overweight and obesity [33]. However, the finding by Hruby \& Hill (2015) [6] among US Army soldiers contradicted this, in which they found that higher education such as having advanced degree seemed to be in a relationship 
with higher odd of overweight/obesity ( $\mathrm{AOR}=1.29,95 \% \mathrm{Cl}$ : 1.21-1.38). This might be because, higher level of education usually correlates with higher income population group where money to buy unhealthy snacks and fast prepared food were not an issue [33]. A balance in having the knowledge on healthy lifestyle and actually practicing it is really needed to overcome this issue.

This study also found that the higher the rank is, the more likely a soldier will be either overweight or obese, consistent with other studies such as the finding by Smith et al. (2012) [34] and Fear et al. (2011) [35]. The rank level in the Army is closely related to the number of years in service. The promotion of an army personnel to the next higher rank is mostly time-based and assessment based [36]. However, rank does not always run in-line with the year of service in army personnel with high Body Mass Index (BMI). This is due to the fact that the army personnel who are overweight/obese, will not be considered for a promotion. Being demoralised, they have little motivation to lose weight. Higher rank comes with higher salary [37], thus increase one's SES. Higher socioeconomic status, were more likely to be the cause for overweight and obese because it will lead to consuming high-calorie food and avoiding physically tough tasks [38].

The army personnel with past injury were more likely to be overweight and obese as compared to those without, consistent with Gregory et al. (2014), who reported that having a history of knee injury showed significant yearly increment in BMI as compared to those without $(p=0.03)$, as well as significant positive difference in body fat percentage between both group $(p=0.009)$ [39]. The consistency of physical training among the army personnel might be affected by the past injury, in which there will either be no or little time and effort being invested in doing physical activities [40]. Findings among injured soldiers in the Hruby et al. (2015), Sanderson at al. (2011), and Teyhen et al. (2016) studies have validated the findings, in which injured soldiers are more likely to become overweight and obese due to limitations in their ability to follow the normal high intensity physical regime in the military, and hence are living life in a more sedentary manner $[6,40,41]$.

Family history of obesity was another predictor of overweight and obesity in this study. study Shi et al. (2014), found the same finding, in which the odds of being overweight and obesity were higher in the respondents with history of having obese sibling and obese mother $(p<0.001)$ as compared to those with no family history [7]. Family history is a complex factor with underlying genetic predisposition, which reflects the effect of shared genetics and environment among close relatives [42]. The latter is made known as family acts as a support system in shared physical and social environment towards either healthy or unhealthy lifestyle. The controversial issue with regards to this is, should the military organization in Malaysia limit the intake of those with positive family history of obesity, in order to reduce the prevalence of obesity among its personnel in the long run?

Out of the eleven predictors found in this study, only two of them are modifiable risk factors which are knowledge on dietary intake and plain water intake. Knowledge on dietary intake finding in this study is similar with the findings by Pengpid \& Peltzer (2014), in which they mentioned that the odd of overweight and obesity was higher in respondents with lower dietary risk knowledge $(95 \% \mathrm{Cl}: 0.41,0.99)[43]$. 
Knowledge is important to help army personnel to differentiate between unhealthy and healthy diet and sedentary with active lifestyles.

Plain water intake was also found to be a significant predictor in this study, consistent with a study on 50 overweight female participants in Mumbai found that body weight, BMI, sum of skinfold thickness and appetite score were lower after 8 weeks in those with good plain water intake $(p<0.01)$ [44]. This could be possibly due to the combination of thermogenesis, distention of gastrointestinal organs, changes in osmolarity besides and appetite suppressing effect of drinking enough plain water [47]. Advocating for proper hydration in the busy army routine will improve and hydration profile and help to promote weight loss.

The military organization in Malaysia has conducted various intervention programmes to combat overweight and obesity including health promotion programmes and lifestyle behavioural changes programmes. Some of the programmes did showed positive impacts in instilling awareness among the army personnel, changes their lifestyle and reducing their BMI, However, the findings in this study are showing that, despite many intervention programmes were implemented over the last 2 decades, the cumulative results of all the interventions showing only minimal impact. A closer look at the military intervention programs revealed that, all the intervention programs were merely a one off ad hoc-event every now and then, and were not a standardized whole army intervention programme. However, the limitation of this cross-sectional study was that it could not determine the temporal relationship between overweight and obesity with the factors. This study design also makes it difficult to draw any conclusions on causal relationships based on the findings.

\section{Conclusion}

The prevalence of overweight and obesity among the army personnel with low SES in Kuala Lumpur camps are high at $41.1 \%$. A better study design in the form of cohort (prospective), or mixed method, should be conducted to really assess all the relevant risk factors for a conclusive data. Intervention must be planned and executed from the top down manner along the chain of command of the military organization. The intervention should be standardized and comprehensive, inclusive, well-structured and evidence-based with more focus on modifiable risk factors to ensure optimal impact.

\section{Abbreviations}

BMI: body mass index; SES : socioeconomic status; MLHR: Military Lifetime Health Record system; PULHEEMS: Physical ,Upper Limb, Lower Limb, Hearing, Right Eye, Left Eye, Mental state and Stability classification system

\section{Declarations}

\section{Ethics approval and consent to participate}


All study procedures were approved by the Malaysian Armed Forces Health Services Ethics Committee.

\section{Consent for publication}

Not applicable

Availability of data and materials

The datasets generated and/or analysed during the current study are not publicly available due to the potential sensitive nature of military healthcare data.

\section{Competing interests}

Not applicable.

\section{Funding}

Not applicable.

\section{Authors' contributions}

NQNAR designed the study, performed data management, data collection, data analysis and drafted the paper. NAMZ supervised the study and edited the paper. MAM supervised the data collection process. RA edited the paper. All authors read and approved the final manuscript.

\section{Acknowledgements}

The opinions or assertions contained herein are the private views of the author and are not to be construed as official or as reflecting the true views of the Malaysian Army Headquarters, Malaysian Armed Forces Headquarters or the Ministry of Defence Office. The authors would like to thank the Secretariat of Malaysian Army and the Royal Medical and Dental Corps for their help during the data collection process. The authors would also express their gratitude to the Director General of Health, Liutenant General Dato' Pahlawan (Dr) Md Amin Bin Muslan for his support throughout this study.

\section{Author information}

NQNAR is a Doctor of Public Health candidate from the Department of Community Health, Faculty of Medicine and Health Sciences, Universiti Putra Malaysia, 43400 Serdang, Selangor, Malaysia. NAMZ is from the Department of Community Health, Faculty of Medicine and Health Sciences, Universiti Putra Malaysia, 43400 Serdang, Selangor, Malaysia. MAM and RA are from the Military Medicine Department, Hospital Angkatan Tentera Tuanku Mizan, 53300 Wangsamaju, Kuala Lumpur, Malaysia

\section{References}


1. World Health Organisation. (2018). World Health Organization fact sheet on obesity. https://www.who.int/news-room/fact-sheets/detail/obesity-and-overweight. Accessed 12 Dec 2019.

2. NMHS. (2019). National morbidity and health survey report. https://www.iku.moh.gov.my. Accessed 15 Dec 2019.

3. Malaysian Army. (2018). Health burden report, Health Section, 3rd Infantry Division, Malaysian Army. Malaysia Army.

4. Razni Shauna A, Zahara A, Suzana S. Obesity indices, cardiovascular risks and physical fitness among male Malaysian security personnel. Am J Prev Med. 2015;13(2):412-21.

5. Sonoda C, Fukuda H, Kitamura M, Hayashida H, Kawashita Y, Furugen R, Koyama Z, Saito T. Associations among obesity, eating speed, and oral health. Obes Facts. 2018;11(2):165-75.

6. Hruby A, Hill OT, Bulathsinhala L, McKinnon CJ, Montain SJ, Young AJ, Smith TJ. Trends in overweight and obesity in soldiers entering the US A rmy, 1989-2012. Obesity. 2015 Mar;23(3):66270.

7. Shi H, Jiang B, Wei Sim JD, Chum ZZ, Ali NB, Toh MH. Factors Associated With Obesity: A CaseControl Study of Young Adult Singaporean Males. Military medicine. 2014 Oct 1;179(10):1158-65.

8. Bin HG, Al-Khashan HI, Mishriky AM, Selim MA, AINowaiser N, BinSaeed AA, Alawad AD, Al-Asmari AK, AIQumaizi K. Prevalence of obesity among military personnel in Saudi Arabia and associated risk factors. Saudi medical journal. 2013 Apr;34(4):401.

9. Hatthachote P, Rangsin R, Mungthin M, Sakboonyarat B. Trends in the prevalence of obesity among young Thai men and associated factors: from 2009 to 2016. Military Medical Research. 2019 Dec 1;6(1):13.

10. Troxel WM, Shih RA, Pedersen ER, Geyer L, Fisher MP, Griffin BA, Haas AC, Kurz J, Steinberg PS. Sleep in the military: Promoting healthy sleep among US servicemembers. Rand health quarterly. 2015 Nov $30 ; 5(2)$.

11. Rush T, LeardMann CA, Crum-Cianflone NF. Obesity and associated adverse health outcomes among US military members and veterans: findings from the millennium cohort study. Obesity. 2016 Jul;24(7):1582-9.

12. Arsenault JE, Noyes M, Funderburk L. Attitudes and behaviors of overweight or obese US Army Soldiers. 2013; 349-5.

13. Mara T, Ma LT, Wang S, Wang L, Yang F, Song JH, Cao YC, Yin JH, Cao GW. The prevalence rates of major chronic diseases in retired and in-service Chinese military officers (2000-2016): a metaanalysis. Military Medical Research. 2018 Dec 1;5(1):4.

14. Nyberg ST, Batty GD, Pentti J, Virtanen M, Alfredsson L, Fransson El, Goldberg M, Heikkilä K, Jokela $\mathrm{M}$, Knutsson A, Koskenvuo M. Obesity and loss of disease-free years owing to major noncommunicable diseases: a multicohort study. The lancet Public health. 2018 Oct 1;3(10):e490-7.

15. Official Orders by the Chief of Army on 20th August. 2014 (MK TD/G1/1767[D\&P]- [50]). 
16. World Health Organisation. (2019). SDG 3: Ensure healthy lives and promote wellbeing for all at all ages. https://www.who.int/sdg/targets/en/. Accessed 12 Dec 2019.

17. National Registration Department. (2019). Maksud B40, M40 dan T20 takrif isi rumah mengikut pendapatan. https://www.permohonan.my/maksud-b40-m40-dan-t20/. Accessed 21 Dec 2019.

18. Lwanga SK, Lemeshow S. World Health Organization. Sample size determination in health studies: a practical manual. World Health Organization; 1991.

19. NMHS. (2015). National morbidity and health survey report. https://www.iku.moh.gov.my. Accessed 15 Dec 2019. (24 - 19).

20. Morrow JR Jr, Krzewinski-Malone JA, Jackson AW, Bungum TJ, FitzGerald SJ. American adults' knowledge of exercise recommendations. Research quarterly for exercise and sport. 2004 Sep 1;75(3):231-7.

21. Jones AM, Lamp C, Neelon M, Nicholson Y, Schneider C, Swanson PW, Zidenberg-Cherr S. Reliability and validity of nutrition knowledge questionnaire for adults. Journal of nutrition education and behavior. 2015 Jan 1;47(1):69-74.

22. Craig CL, Marshall AL, Sjöström M, Bauman AE, Booth ML, Ainsworth BE, Pratt M, Ekelund UL, Yngve A, Sallis JF, Oja P. International physical activity questionnaire: 12-country reliability and validity. Medicine \& science in sports \& exercise. 2003 Aug 1;35(8):1381-95.

23. Hedrick VE, Comber DL, Estabrooks PA, Savla J, Davy BM. The beverage intake questionnaire: determining initial validity and reliability. Journal of the American Dietetic Association. 2010 Aug 1;110(8):1227-32.

24. Backhaus J, Junghanns K, Broocks A, Riemann D, Hohagen F. Test-retest reliability and validity of the Pittsburgh Sleep Quality Index in primary insomnia. Journal of psychosomatic research. 2002 Sep 1;53(3):737 - 40.

25. Rampal GR, Sidik SM, Rampal S, Wong DY, Chow PL, Liew JS, Shum YS. Prevalence of overweight among secondary school students in Klang district, Selangor. Malaysian Journal of Nutrition. 2007;13(1):1-8.

26. Folkman S. Stress Questionnaire. Wellness Self-care. 2011;12(8):124-34.

27. Sabri F, Ariffin MY. Correlation Between Defense Mechanisms and Readiness to Change Among Relapsing Addicts. Malaysian Journal of Social Sciences and Humanities (MJSSH). 2018 Aug 26;3(4):30-4.

28. Reyes-Guzman CM, Bray RM, Forman-Hoffman VL, Williams J. Overweight and obesity trends among active duty military personnel: a 13-year perspective. American journal of preventive medicine. 2015 Feb 1;48(2):145 - 53.

29. Rozita Z, Lim MT, Lee HS. Prevalence of elevated body mass index condition and its associated demographic variables among adults in urban areas in Johor, Malaysia. Med J Malay. 2019 Apr;74(2):145-50.

30. Teachman J. Body weight, marital status, and changes in marital status. Journal of family issues. 2016 Jan;37(1):74-96. 
31. Cobb LK, McAdams-DeMarco MA, Gudzune KA, Anderson CA, Demerath E, Woodward M, Selvin E, Coresh J. Changes in body mass index and obesity risk in married couples over 25 years: the ARIC cohort study. American journal of epidemiology. 2016 Mar 1;183(5):435 - 43.

32. Ghee LK. A review of adult obesity research in Malaysia. Med J Malaysia. 2016 Jun 1;71(1):7.

33. Kim TJ, von dem Knesebeck 0 . Income and obesity: what is the direction of the relationship? A systematic review and meta-analysis. BMJ open. 2018 Jan 1;8(1):e019862.

34. Smith TJ, Dotson LE, Marriott BP, Bathalon GP. Overweight and obesity in military personnel: Sociodemographic predictors. Obesity. 2012;20(7):1534-8.

35. Fear NT, MacManus D, Dean K, Iverson AC, Hull L, Jones N, Fahy T, Wessely S. Impact of preenlistment antisocial behaviour on outcomes among UK military personnel. Soc Psychiatry. 2011.

36. Malaysian Army Headquarters. (2016). Army 4 to Next Generation. Malaysian Armed Forces, Cawangan Percetakan 91 DPO.

37. Malaysian Army Headquarters. (2019). Situational force scoring 2019. Malaysia Army Headquarters.

38. Pampel FC, Denney JT, Krueger PM. Obesity. SES, and economic development: a test of the reversal hypothesis. Social science \& medicine. 2012 Apr 1;74(7):1073-81.

39. Myer GD, Faigenbaum AD, Foss KB, Xu Y, Khoury J, Dolan LM, McCambridge TM, Hewett TE. Injury initiates unfavourable weight gain and obesity markers in youth. British journal of sports medicine. 2014 Oct 1;48(20):1477-81.

40. Teyhen DS, Rhon DI, Butler RJ, Shaffer SW, Goffar SL, McMillian DJ, Boyles RE, Kiesel KB, Plisky PJ. Association of physical inactivity, weight, smoking, and prior injury on physical performance in a military setting. Journal of athletic training. 2016 Nov;51(11):866-75.

41. Sanderson PW, Clemes SA, Biddle SJ. The correlates and treatment of obesity in military populations: a systematic review. Obes Facts. 2011;4(3):229-37.

42. Sandholt CH, Grarup N, Pedersen $\mathrm{O}$, Hansen T. Genome-wide association studies of human adiposity: zooming in on synapses. Molecular and cellular endocrinology. 2015 Dec 15;418:90-100.

43. Pengpid S, Peltzer K. Prevalence of overweight/obesity and central obesity and its associated factors among a sample of university students in India. Obesity research \& clinical practice. 2014 Nov 1;8(6):e558-70.

44. Vij VA, Joshi AS. Effect of excessive water intake on body weight, body mass index, body fat, and appetite of overweight female participants. Journal of natural science biology medicine. 2014 Jul;5(2):340. 